\title{
LOSS AND LONGING IN THE ZOHARIC READING OF EICHAH
}

\section{PERDA E DESEJO DE RETORNO NA LEITURA ZOHÁRICA DO EICHAH}

\author{
Gabriela Ripper Naigeborin*
}

\begin{abstract}
This essay proposes a close analysis of the introduction to the Kabbalist text known as Midrash ha-Ne'lam al Eichah, an interpretation of the biblical book of Lamentations which integrates the medieval text of the Sefer ha-Zohar. While the biblical version centers the destruction of the First Temple in 586 B.C.E., the medieval narrative of the Midrash ha-Ne'lam opens with an anachronistic argument between the two Jewish communities historically formed with the fall of the First Temple: the one in Babylon, the symbol of the Jewish Diaspora, and the other in Jerusalem, the heart of the Holy Land of the Jewish people. Collapsing the destruction of the First Temple with the subsequent destruction of the Second Temple in 72 C.E., the Midrash ha-Ne'lam intersperses literal and figurative meaning to craft a cosmic narrative of loss and longing, which runs parallel to the original biblical account. By focusing on the argument between the Babylonian and Jewish communities, the present article probes into a tension that structures the Jewish condition in the diaspora: the combination of material distance from, and spiritual attachment to, one's sacred homeland, induces a state of spiritual homelessness. The Midrash ha-Ne'lam paints the "competition" for the right to mourn the loss of the Temple as a family argument between those who stayed in the destroyed homeland and those who have strayed from it many generations before, a tension that reverberates to this day on the inner division between diaspora and Israeli Jews.
\end{abstract}

Keywords: Judaism. Kabbalah. Zohar. Diaspora. Medieval Mysticism.

Resumo: Este ensaio propõe uma análise da introdução do texto Cabalista conhecido como Midrash ha-Ne'lam al Eichah, uma interpretação do livro bíblico das Lamentações que compõe o texto medieval do Sefer ha-Zohar. Enquanto a versão bíblica foca na destruição do Primeiro Templo em 586 A.E.C., a narrativa medieval do Midrash ha-Ne'lam começa com uma disputa anacrônica entre duas comunidades judaicas formadas historicamente com a queda do Primeiro Templo: uma na Babilônia, o símbolo da diáspora judaica, e a outra em Jerusalém, o coração da Terra Sagrada do povo judeu. Colapsando a destruição do Primeiro Templo com a subsequente destruição do Segundo Templo em 72 E.C., o Midrash ha-Ne 'lam entremeia literalidade e figuração para construir uma narrativa cósmica sobre perda e desejo de retorno, a qual corre em paralelo com o relato bíblico original. Ao focar na discussão entre as comunidades da Babilônia e de Jerusalém, o artigo presente examina uma tensão estruturante da condição judaica na diáspora: a combinação de distância material de, e ligação espiritual com, uma terra sagrada, induz um estado de destituição espiritual. O Midrash ha-Ne'lam descreve a "competição" pelo direito de lamentar a perda do Templo como um argumento de família entre aqueles que ficaram na terra destruída e aqueles que se desviaram desta há muitas gerações, uma tensão que reverbera até hoje na divisão interna entre os judeus da diáspora e judeus israelenses.

Palavras-chave: Judaísmo. Cabala. Zohar. Diáspora. Misticismo Medieval.

\footnotetext{
* Bacharel em Literatura Comparada e Psicologia pela Universidade Brown, e mestre em Literatura e Cultura Comparadas pela Universidade de Cambridge. Email: <grnaigeborin@gmail.com>.
} 
The Midrash ha-Ne'lam al Eichah (Hidden Midrash on Lamentations) opens with a dispute between the "residents of Babylon" and the "residents of the Holy Land" for the right to moan the destruction of the Second Temple. ${ }^{1}$ In line with other works in the Sefer ha-Zohar ("Book of Splendor"), a core text of Iberian Kabbalah dating back to the early $13^{\text {th }}$-century writings of Moses de León, this medieval reading of the biblical text seeps with the substance of the intradivine drama that occupies a special place in Kabbalist theosophical mythology. In the Pritzker edition of the Zohar, "residents" stands in for the Hebrew bnei, which literally means "children" or "sons". By retaining the familial undertones of the story in a latent state, the opening lines of this translation of the Hidden Midrash suggest that the text with which we are dealing consists of layers upon layers of concealed meaning. A number of relations might be adduced if we read "residents" and "children" interchangeably throughout the text, and the process by which these terms are made equivalent itself deserves a closer look.

This initial tension is but one of those that I intend to delineate in this literary rendering of themes in framing narrative in the Midrash ha-Ne'lam on Lamentations. The focus of my specific efforts here will be on one particular manifestation of longing - a dominant motif throughout the opening paragraphs of the midrash - which is that of longing for the event of homecoming. In this sense, I will touch on some of the other manifestations of the same feeling but will largely approach them through the aforementioned lens. What kind of idea of home does the passage conjure up? What does the hope of return consists of, and how does distance from home, along with the accompanying longing that trails after it, interacts with the myth of the separation of the Shekhinah (the tenth sefirah) ${ }^{2}$ from the blessed Holy One (the sixth sefirah) - a break in the divine that directly affects the relationship of these entities to the children of Israel?

I will divide this essay into different sections, each structured around a particular theme that called my attention in my reading of the passage. As the mode of the text is one of association, the tensions, connections, contrasts and contradictions that I investigate in each section flow across different sections - whose topics are somewhat arbitrarily determined - and recur in, or overlap with, those explored in other parts of my analysis. My goal here is to outline each topic in the likeness of a carp swimming downriver-discernible in the stream of the text as, ever elusive, it flows freely past our feet, its presence a mysterious glimmer underwater.

\section{Children and residents}

In the original text, Bnei Bavel, which literally means "children of Babylon", takes advantage of the commonplace metaphor used to refer to the natives of a nation or land as that place's children. Interestingly, the double entendre arises not from a parallelism between nativity and filiation, but rather between filiation and residency. As opposed to nativity, residency in a place conveys the idea of a more circumscribed kind of belonging, one bound by time and limited by external circumstance. In short, the main distinction between these two

\footnotetext{
${ }^{1}$ A collection of poetic laments in Ketuvim centered on the conquest of Jerusalem and the destruction of Holy Temple.

${ }^{2}$ The sefirot are ten divine attributes, or channels of divine manifestation in the Created world, that arrange themselves as a system. First mentioned in the Sefer Yetzirah ("Book of Formation"), an ancient precursor to different strains of medieval Kabbalah, the Sefirotic system that underpins the $13^{\text {th }}$-century literature of the Zohar is synthesized in the $16^{\text {th }}$-century writings of Moses Cordovero. The reformulation of the Sefirotic system by Cordovero's contemporary, Isaac Luria, gives rise to a second major interpretation of this system, which is typically contrasted with the Zoharic and Cordoveran views.
} 
criteria corresponds to different kinds of belonging. While it seems correct to conclude that the native of Babylon is from Babylon, one could only go so far as to say that a resident of the same nation is in Babylon for a period of time, and in that capacity bears a connection to it. The very act of mourning for the loss of Jerusalem indicates the troubled nature of this community's relationship to their home: there is a dissociation between the lost home of the Bnei Bavel in Jerusalem and their defining place of abode in Babylon. The qualified sense of belonging that provisionally ties the Babylonian Jews to diasporic land legitimates this community's mournful longing for their spiritual home in Jerusalem. Longing and belonging are thus revealed as the two complementary facets of the diasporic identity forged by the Bnei Bavel, which is marked by their separation from a spiritual mother (the Shekhinah) and a material mother (Jerusalem, their "motherland").

The translated text's reference to the members of the different Jewish communitiesBabylon and Jerusalem - as residents rather than natives, in spite of the fact that those communities had, at that point in history, already been established in those lands for generations, opens up interesting, albeit perhaps unintended, interpretations regarding the connection of those communities to the lands they were settled in as well as one another. First off, no sense of rootedness goes so deep as to ensure protection against uprooting; secondly, the tension existent between the two communities seems to be based more on historical constraints than on any sort of essential distinction. The "missive" communication that makes evident the clash between the two communities is befitting of both the exegetical portion and the framing narrative of Midrash ha-Ne'lam al Eichah, which is precisely about broken communication that ensues between two long-distanced parts of the same entity. In a way, Shekhinah's and the blessed Holy One's mutual incompleteness is formally materialized in the competing correspondences exchanged between one community and the other.

Just as the rendering "residents" distances both communities from their respective lands, the literal reading - at once a conventional metaphor and a mythological approach - of the correspondents as being the "children" of Babylon and the Holy Land brings each of those closer to the lands with which, as the text points out, they bear filial ties. Put differently, as one reading of the term relativizes (or at least makes arbitrary) each community's ties to their corresponding lands while bringing them closer together, the alternative reading grounds each to the lands from which they write, pitting them against each other and justifying the competitive strain that the text takes on. Interestingly enough, the same fraternal competition that appears as a common trope in stories of family drama is only made more intense by a reading that constitutes each group as the children of a different land, although the reason for the debate are the competing claims to the same filiation. In this sense, the very beginning of the Midrash contains a fine tension between the "House of our God" (298), elsewhere referred to as "Her household" (300), which is a shared spiritual space to which both communities feel they have a claim, and in which both feel they belong, and the concept of the "homeland", which in itself is a fragile designation for the physical spaces from which each community is writing.

\section{Seeking home, seeking gods}

The Babylonian Jewish community makes its argument:

Eulogizing the destruction of the House of our God befits us since we have been scattered among the nations, like idol-worshipers. We should be the ones to begin the lament, and to expound the alphabetic acrostic sent by the Master of the Universe, bemoaning the destruction of His House (298). 
In this long-distance discussion, each of the communities lays down its claim to the interpretation of Lamentations, an activity that itself consists, on the one hand, of directing the affective-symbolic event of lamentation and, on the other, of the theosophico-mythical interpretation of the Book of Lamentations. In their claim for the worthiness of their taking up this enterprise, the Babylonian community's train of thought is straightforward: the pain that comes with having been "scattered among nations, like idol-worshipers" seems compatible with the task of bemoaning the destruction of the Temple.

First and foremost, let us examine the comparison drawn by the Babylonian community: their experience of the diaspora is likened to idol worshipping. The crux of the comparison lies in this community's removal from the Holy Land. Distance from the "House of our God", which translates as a form of religious homelessness, is at the root of the sense of godlessness that spurs a condition as deplorable as idolatry - which can quite plainly be understood as a search for God. ${ }^{3}$ The negative parallel between homelessness and perceived godlessness implies a correspondence between home and God, both of which they are deprived of. More than a sin, this abject state comes across here as a sign of despair-a last resource that leaves those detached from God more deserving of pity than punishment. Although God is still referenced as "our God", an implicit distance is inscribed in that very reference, as the Temple is referred to first as "House of our God," and later as "His House", with no mention within the text to the Babylonian Jews' belonging to that House. All in all, the claim is to the "eulogizing" or "bemoaning" of the destruction of God's House rather to the House itself, and it is their being away from that space that ultimately guarantees their contender's victory.

Finally, the destruction of the Temple signifies a radical disruption of the household not only on a deeply personal level - the Temple being akin to the private abode of each Jew-, but also to an all-encompassing degree. If God is described as the "Master of the Universe" as much as master of the house, then destruction of his earthly home would certainly shake its heavenly correspondent. Hence, the destitution of the people of Israel is so complete that it does not seem excessive to assume that the conundrum posed by the destruction of the Temple bears the dimensions of cosmic homelessness.

\section{Orphans vs. runaway slaves, exile vs. diaspora}

The destruction of the sacred House would in a way impact the Babylonian community more than it would the Jerusalem one. The very fact they use distance as a reason for their grief - being away from it and dispersed from one another - could be said to undermine their claim.

It befits you to be scattered among the nations and to be outside the Holy Land. It befits you to weep for yourselves, for the very fiber of your being, for you abandoned light for darkness, like a slave leaving the house of his master. As for us, we should be the ones to weep and lament. To us the blessed Holy One sent a book of lamentations, for we are the children of the Matronita, and we are the members of Her household. We know the glory of the Master of the

\footnotetext{
${ }^{3}$ This idea is made even clearer in a passage in the Babylonian Talmud: "Whoever lives in the land of Israel is like one who has a God; whoever lives outside the land of Israel is like one who has no God. This is as is said, To give you the land of Canaan, to be your God (Leviticus 25:38). Has one who does not live in the land no God! Actually, the verse comes to tell you that whoever lives outside the land may be regarded as one "who worships idols" (BT Ketubot 110b).
} 
Universe, thus it befits us to weep and interpret those acrostics. We are orphans, without Father or Mother! (298).

The actual destruction of their House - that is, of their religious center of gravity or their people's organizing principle-happened much time before, in the sixth century before the Common Era, which marked the beginning of the Babylonian exile to Babylon. Incidentally, the exile that demarcates the separation - and thus creation by means of division — of both communities came precisely with the destruction of the First Temple, the original House of God. At the loss of that first house, the Jerusalem community accuses, the group that would establish the Babylonian community deserted the Holy Land "like a slave leaving the house of his master", and it is the memory of that first "desertion" that the Jerusalem community uses to hold that group's successors accountable, and remove from them the privilege of a first interpretation. They all lost a House, but while the first, like servants, left, the latter, in staying, not only confirmed their loyalty to the Land, but in a way "revealed" that they were the children of the Master of the House - this revelation a becoming by means of confirmation.

This community's "abandonment" of God's abode thus precedes God's abandonment of it, manifested as the blessed Holy One's departure, and culminating in the defilement of the Shekhinah by the Sitra Ahra. ${ }^{4}$ In this passage, a slave's desertion of her master's house is likened to abandonment of divine light for demonic darkness. From that one might conclude that the attempt at freedom has diaspora as its punishment, and that what lies outside the master's domain - the otherness beyond the threshold of known territory-pertains to the realm of the demonic. Paradoxically, freedom as such is borne out of the subjects' sense of imprisonment and desire to escape - and comes at the price perceived abandonment by God. As a Talmudic passage underscores, the difference between the child and the servant lies in the fact that the first submits to God's desire, whereas the latter resists, refuses and ultimately escapes it. ${ }^{5}$

At the core of the argument that the Jerusalem community puts forth is the implicit accusation that the Babylonian community's condition is better described as bringing one of diaspora rather than exile per se. "Diaspora" derives from the Greek word diaspeirein, to scatter across, to disperse. Indeed, "scattered" is the precise word with which the Jerusalem Jews describe the state that they think befits their Babylonian counterparts. Alternative meanings to spora and speirein, to scatter, include "to sow", "to sprout", and "seed". Conversely, the nearsynonym "exile" comes from the Latin exul, the word for "banished person". In other words, not only do these two translations of the Hebrew galuth - which are often used interchangeably in relation to the Jewish experience of "homelessness" or foreignness - stem from different linguistic origins; their original meanings belong to different semantic fields. While exile encloses a sense of uprootedness, diaspora points precisely towards its opposite — a sowing or

\footnotetext{
4 "Eikhah, Alas! She sits alone, the city once full of people (Lamentations 1:1). It is written: 'For it was a day of din and tumult and confusion to Adonai YHVH, My Lord God, of Hosts in the Valley of Vision, of battering down the wall, and of crying to the mountain' (Isaiah 22:5)" (303) The mystical reading offered by the Hidden Midrash explains these passages from Ketuvim and Nevi' im in terms of the struggle between the Shekhinah and the demonic realm - one of the main conflicts staged in the Zohar. In line with other Zoharic interpretations of biblical material —which employ the Sefirotic system as a major conceptual and linguistic framework- "כה" (the 25 letters of the first line of the שמע), "She", "the city", "people" and "Valley of Vision" (Jerusalem) could all be read as standing for the Shekhinah. Similarly, "a day of din and tumult and confusion", "battering down" and "mountain" all represent the Sitra Ahra. "To" (directionality of impact and affect), "hosts" and "crying" are some of the core themes explored in this essay.

5 "You are called both sons and servants. When you carry out the desires of the Omnipresent you are called 'sons', and when you do not carry out the desires of the Omnipresent, you are called 'servants"” (BT Bava Batra 10a).
} 
sprouting that indicates the potential setting down of roots. In accusing the Babylonian Jews of self-banishment or, in a way, of bringing about their own transformation into slaves - or condition of slavery-, the Jerusalem Jews mark their experience off the Babylonians': if the destruction of the First Temple established the beginning of the Babylonian diaspora, the destruction of the Second Temple created the Jewish exile for the Jerusalem community. If the distinction between these conditions already denotes different rights to lamenting and interpreting, as well as index different kinds of belonging to the Land, then it must also bear different implications for the Jewish right to return.

The kind of weeping that is permissible for the Babylonian Jews is self-contained. As the Jerusalem community puts it, they must cry "for the very fiber of [their] being". On the one hand, this statement means a negation of their right to lament anything other than their very being, such as the tragic loss of God's household - which would imply a connection to that household. On the other hand, it places affirmative emphasis on the need to lament-not the loss of a home, but a loss (self-abandonment) of themselves to the forces of evil. In contrast, the Jerusalem Jews' belonging in the House of God grants them knowledge of the glory, which in turns allows them, as orphans, to reclaim the grief for something larger than themselves. In this sense, the loss of a Father or Mother is conditioned by their previous obeisance to God, which also ensured their salvation. "Legitimate" loss of one's home-the Temple - not only incurs in self-loss, but also requires not having lost oneself as its pre-condition. Hence, capture of the Shekhinah by the forces of the Sitra Ahra is already infused with hope, since those who suffer from Her demise have at least safeguarded their being, and thus their potential to save her.

\section{Walls and days} destruction:

The Jerusalem community then goes on to describe their pain upon the Temple's

We cast our eyes upon the walls of our Mother's house, but it is destroyed, and we can't find Her-She who used to suckle us from Her soothing bosom, every day in those ancient days. She used to console us and speak to our hearts, like a mother to her son, as is said: Like a man comforted by his mother... (Isaiah 66:13) (299-300). ${ }^{6}$

In the midst of the ruins, they look up at the Temple's walls, its only remains. In this context, "walls" (קיר) signify the Lower Mother Shekhinah, and it is by this name that the Upper Mother Binah (317) will inquire after Her Daughter (Shekhinah) later in the text. The relationship between house and divine motherhood is overdetermined: according to one reading, the Jews cast their eyes at the Temple. This reading subdivides into two. In the first one, "Mother" is understood to be Shekhinah, and the Temple is rendered as Shekhinah's former place of abode, where she cannot be found anymore. In the second reading, if one reads Binah's later appearance as being hinted at in this passage, so that "Mother" is understood as Binah, then the master of the house is Binah, and when the Jews reminisce, "we can't find Her", they place themselves side by side with the Upper Mother in her pursuit of the missing Daughter. Alternatively, the "Her" in "we can't find Her" does not refer to the object of Binah's

6 “...so I will comfort you, and you shall find comfort in Jerusalem” (300). Once more the community of Jerusalem identifies itself with the Holy Land and the Temple, which, too, is again associated with a mother in which a child finds her home. 
quest, but Binah herself. This offers us an inverted reading in which the Jews, as ravaged as Shekhinah - the "walls" with whom they communicate through an understanding glancealign themselves, tied by their their shared state of destruction, with the defiled Daughter in Her desperate search for nourishment. As Shekhinah is banished together with Her people, and cohabits with them the experience of exile, this association seems consistent with Her relationship with Israel, which is one of interdependence and, above all, close identification.

This latter reading presents Shekhinah as the walls of the Temple itself, and thus as a constitutive part of it. We circle back to the beginning of the passage, and "Shekhinah" is privileged over "Temple" as the primary signified for "the walls of our Mother's house". They cast their eyes upon Shekhinah, who could be both - and indeed is both, as all of these readings are in fact simultaneous - Her own house, if she is looked at as the "Mother" of Her people and the text is read from their viewpoint, in relation to them, or Her Mother's house. Indeed, the idea of the Daughter as the Mother's home, albeit seemingly inverted at first, seems compatible with the experience of Motherly worry. The picture here is even more pitiful: Israel (alongside Binah or not) look directly at Shekhinah, but She, the house, is destroyed, and nowhere to be found in the eyes into which they are so miserably staring-She is not Herself. Even gloomier is the reading that presents Shekhinah as Her own home, since not finding Herself in this case means lack of self-recognition. This is a rich picture of great trauma, and of a trauma eliciting emotions consistent with the ones being described here-dissociation, guilt, self-punishment, regret and, above all, deep sadness at a loss and a lack.

We have held "walls" constant — its meaning arbitrarily designated as "Temple" — and performed readings of "Mother" as both Shekhinah and Binah. Then, we took "walls" to signify Shekhinah, and designated Mother first as Binah — with Shekhinah as Her house-, then as Shekhinah - understood as an entity residing in Herself. Another possible reading presents Binah as the house's - the Temple's - "walls", to the extent that Binah is Tiferet's heavenly home $^{7}$, which has its sacred earthly correspondent in the Temple. This reading highlights Binah's role as both a Mother to Shekhinah and, by means of her all-embracing Motherhood, a Mother to Israel. It also gives us a coherent picture of the subsequent childhood reminiscence"She who used to suckle us from Her soothing bosom, every day in those ancient days"-as being oriented towards a past that is further away - a past that belongs more to itself, the past, than to the person reminiscing. This past is the original past, as "ancient days" could be a name for Atika Kadisha, the Holy Ancient One, the day that came before the six days of creationthe six "middle" sefirot - that the blessed Holy One encapsulates, and the day of Shabbat (Shekhinah), from which they withdraw. Binah, the Mother and Mother-of-the-Mother suckling Her people is soothing them in her bosom, which is located in —or equaled to - "those ancient days".

More than a portrayal of the family, what we have here is a portrait of generational ties, as Atika Kadisha is also Grandfather. As Grandfather he is both Father to Binah, to Shekhinah and to Israel, as well as counterpart for Imma Ila'ah, the Upper Mother. That this intergenerational connection takes place at the point of the text in which suckling is mentioned is telling, as the sefirotic flow that suckling represents is what nourishes, at once, text, Israel and the multiple aspects of God. Therefore, it seems natural that nodal points of meaning would also be swellings of divine nurture - which also work as an outward manifestation of hurt in the text.

The narrated experience of loss begins to resemble, more and more, the primordial experience of lack. If "loss" seems like something that cannot be re-attained, the impossibility

\footnotetext{
7 "But man is going to his everlasting house" (335) signifies Tiferet's ("Man") ascension to Binah, his house and Mother. Ironically, it is Tiferet's retreat into the heights that leave his consort and sister vulnerable to the attacks of the forces of evil, symbolized by the snake. This signals to the function of the demonic in fraternal competition.
} 
in "lack" is not one of re-attaining, but of attaining in the first place. This distinction marks the entry point for messianic imagery and the concept of the "hope of return", one so consistent with the untenable desire of the exiled: "hope" is a propulsion into the ever-imagined future, "return" a thrownness into the longed-for past. Two of Keter's names further highlight the temporal dimension of this passage, and of the intention it foreshadows: The Patient One is constantly waiting; in Him the primordial past is suspended, as is the future it awaits. On the other side of the equation, I Will Be (אהיה) forever promises, and it is this promise that fulfills the drive, and feeds into the raison d'être, of this unfulfilled expectation. Historical rupture takes on its full meaning: the destruction of the Temple made possible by the departure of the substitution of the days of creation and rest by "a day of din and tumult and confusion" (Isaiah 22:5) pinpoints a traumatic discontinuation of time. In other words, a rip in the somewhatunified tradition of the Jerusalem community accompanies an increased awareness of the past.

Now, our eyes dart about in every direction. The site of our Mother's dwelling is in upheaval - destroyed. O, let us bang our heads against the walls of Her house and Her dwelling. Who will comfort us? Who will speak to our hearts and protect us before the King? (301).

Their eyes' detachment from the solidity of the still-standing wall, and confused migration to from one direction to another, is metonymic of the moment in which the portion of the Jewish community inhabiting the Holy Land was about to enter. To have one's "eyes dart about in every direction" means to not know where to look-where to look for God, for solace, for the consolation found in a Mother's "soothing bosom". Therein also lies the danger of moving towards the north, where the demonic throne is to be found. As the passage indicates, this confusion of the eyes corresponds to a confusion of the heart not being spoken to.

This paragraph adds to the connotations that "walls" had accumulated in the preceding one. The walls of the site of the Mother's dwelling are what remain of the house. Interestingly, one would expect the outermost part of the house to be the first one to go down under the attack by the forces of the demonic. The walls seem to serve two main goals: setting the limits of the domain over which God exerts Her power and protecting this territory. Walls, fence and limits function interchangeably here: as legal limits surrounding the commandments, they determine what moral and religious practices lie within God's territory, and which belong to the demonic realm. ${ }^{8}$ This seemingly more abstract meaning gives way to its mythical correlate, one expressed as geopolitical boundary rather than a "merely" legal one. The mythological strain of the Kabbalistic text undoes metaphor: it evidences the precariousness of the literal-figurative divide, as it is clear that geopolitical limits are as physical as they are political, and that legal boundaries both bear a political character and material consequences.

Logically, these "walls" or "fences" were erected at those ambiguous spaces "where people are likely to be lax in observance" (305). Because the place between the divine and the demonic is the most vulnerable in the Universe, it is precisely there that the serpent will lurk and wait to bite those who err. The walls - the last part of the house standing, and a feature that helped sustain it—seems to represent the Shekhinah as much as they represent Her people. The walls around Her, which both protect and sustain Her dwelling place, are at once the strongest and most vulnerable point of entry for the serpent into the sefirotic structure-hence the ambivalent role they play in the tragedy of the Temple's destruction. Interestingly, the walls do

\footnotetext{
8 "The rabbis erected "fences," legal stringencies designed to protect the inner core of the commandment, but the serpent loiters near those fences - where people are likely to be lax in observance - and pounces when they slacken. By pounding the Shekhinah down to the ground, the serpent foists onto Her the curse that was laid upon it (305).
} 
not seem to protect divine structure from the evil outside. Kohelet 10:8 tells us that "He who breaches a wall-a snake will bite him, which provides the prudent warning that when dismantling a stone wall, one should be cautious - for its cavities may well conceal a snake's lair" (306). ${ }^{9}$ The snake punishes those that do what it did with the very punishment it received from God for its evil deed: it punishes the Shekhinah by bringing Her to the ground, and the ones it bites and kills are those who "make breaches in fences"- that is, break divine law. The serpent is a repeater; all it seems to do is find breaches for the contradictions inherent to the divine drama to leak through. The dynamic interaction between the venom of the serpent's bite and the sefirotic fluid animates all levels of existence, from lowest to highest.

\title{
Learning and teaching a language
}

The text continues to describe the divine drama, in which the Mother Shekhinah protects Her children from the Father's unmeasured judgment. Given that the exceeding gushing of Gevurah plays an important part in the creation of the Sitra Ahra, the inflated strikes that the King inflicts as a punishment for His subjects'-His children's-sins are but a compulsive repetition containing, as potency, the tragedy that ensued upon His retreat.

\begin{abstract}
When we used to sin before our Father and the lash would shoot up to strike us, she would stand in front of us and receive the flogging from the King, protecting us. This is as is said: But he was crushed for or sins, wounded for our iniquities (Isaiah 53:5). But now, we have no Mother! Woe unto us! Woe unto you, afterward! It befits us to weep, it befits us to wail. If befits us to explain these words of bitterness, to teach those experts in ululation the language of lamentation (301).
\end{abstract}

In describing Shekhinah's willingness to dive into the eye of the storm-from which she would emerge not only dignified and noble, but also whole - the Jerusalem community shrewdly places itself at the center stage of the cosmic drama, due to their central role in the divine family drama. ${ }^{10}$ The Shekhinah is punished "in their place", in both meanings of the phrase: she is punished instead of them, for their sake and protection, and she is also punished where they are. Because they were there and witnessed her suffering, they learned-not only from her suffering, but the suffering itself. Simply being there and seeing their Mother's pain in a way "taught" them how to suffer in a manner compatible with her own. Pain thus seems to be vicariously transmitted and witnessing takes on a didactic value in this process. It is by means of their presence that the Jerusalem Jews learn the proper language of lamentation, the language in which they will be able to adequately weep and wail for the loss of the Temple.

There is something to be said about learning the "right" language to mourn, and the means for attaining such knowledge. For one thing, the language of one's reaction must resonate with the language of the action being taken in and interpreted. Indeed, claims to the ability to provide a befitting interpretation are often bound to the assertion that one is familiar with the material at hand. In short, the underlying contention here is that one needs to listen before

\footnotetext{
9 "Rabbi Shemu'el son of Nahman said, 'The serpent was asked, "Why are you generally to be found among fences"? He replied, "Because I made a breach in the fence of the world"' Rabbi Shim'on son of Yohai taught: The serpent was the first to make a breach in the world's fence, and so he has become the executioner of all who make breaches in fences"' (Vayiqra Rabbah 26:2, Vilna).

10 "Yet it was our sickness that he was bearing, our pains that he endured - though we considered him plagued, stricken by God and afflicted. But he was wounded for our sins, crushed for our iniquities; he bore the chastisement that made us whole and by his bruises we were healed" (Isaiah 53:4-5).
} 
speaking and watch before explaining; the "bitterness" of the words needs to be tasted before it can be expounded.

\section{Progressive personification and liminal space}

At this point the wandering subjects describe the exhausting searching routine they embark on daily, which proceeds over a series of ritualized steps. At each familiar object they encounter in Her chambers, a question is posed. However, the destination of the question changes as the passage - and the night — runs by:

Every day we approach Mother's bed, but we do not find Her there. We ask after Her-no one heeds us. We ask after Her bed—overturned. We ask after Her throne-collapsed. We ask Her palaces - they swear they know nothing of Her whereabouts. We ask the dust - no footprints there.

We ask the rooftop, and the rooftop replies that She had been sitting there weeping and wailing. But she had trudged on, sobbing, shrieking grievously for us from rooftop to rooftop. This is as is written: What has happened to you now, that you have gone, all of you, up on the roofs? (Isaiah 22:1) We ask of the pathways and boulevards, and they all reply that they head an agonizing sound of weeping, weeping for Her children, but they know not where She disappeared (302).

First, they ask after Her bed, then they ask after Her throne, both of which are reduced to shreds of her presence - and markers of her absence. Suddenly they cease to ask after and begin to destine questions at the objects directly: they ask Her palaces, which reply that they know nothing of Her. They ask the dust, to which it replies with an absence of signs. The palaces reply verbally, whereas the dust makes use of another use of answering. Interestingly, what it substitutes a verbal answer for is not a symbol, but a different kind of sign - an index. Footprints differ from mere symbols in that they are the actual imprints of the thing they signify. They are left behind in the process of becoming a form of, and instrument for, representation. In short, they are part and parcel of the story they tell, and so they tell what they effectively are. In this sense, they are metonymic of a number of elements that I deem essential to this story, such as the Temple, tradition, human action in relation to divine happening, and writing.

The next to be asked are the rooftops, which are the balconies "from which people leapt to their deaths during the horrors of Jerusalem's destruction. The rooftop is also one of the stages that the Shekhinah mounts as She leaves Jerusalem" (302). The rooftops function as a liminal space between ascension and descent. Interestingly, although rooftops seem to represent an intermediary level between Earth and Heaven, as it is the uppermost plane of the terrestrial, it is from there the Shekhinah, who is ensnared by Sama'el, leaves the Jerusalem and enters the Other Side. Shekhinah's contradictory departure mimics that of those who kill themselves at the sight of violent destruction of their home: they leap down into their deaths, but in dying their soul is released into the divine home hidden above.

\section{Transmission through space and time}

Weeping and mourning are animating activities in that they help, quite literally, keep the memory of the Temple alive. 
It befits us to weep, it befits us to mourn. O, let us kiss the walls of Her palace, sobbing bitterly! We shall be the ones who begin the wailing-we see this every day! O, let us weep constantly, and never forget the bitterness of our tears!" (302).

In one sense, the memory of the Temple is kept alive in the minds and stories of those "weeping constantly". Their incessant weeping is an effluent telling that ensures that they never forget the bitter taste of what is being told. To sob and weep bitterly is to never stop telling, but in such a way that the sobbing and the weeping themselves produce the story being reproduced. That might just be the reason why the framing narrative for the interpretation of Lamentations is a competition to decide who is more fitting to weep and mourn: those who weep are those who get to tell the story, and a befitting weeping is nothing but a suitable recreation of the memory of the mythical event. Within the framework of mythical thinking, tale, ritual and religious belief are all nourished from the same substance, which is human activity and expression. Crying, wailing and kissing the walls of the devastated palace are affective reactions that, more than sustain the memory of the Temple, endow it with an "aliveness" of its own: the Temple is not just remembered; it remembers-it remembers us as much as we remember it. And, for all we know, the path of mutual reminiscence might conceal the way back home.

\section{Referências Bibliográficas}

BLOOM, Harold. Kabbalah and Criticism. New York: Seabury Press, 1975.

GREEN, Arthur. A Guide to the Zohar. Stanford: Stanford University Press, 2004.

MATT, Daniel C. The Zohar: Pritzker Edition. Stanford, CA: Stanford University Press, 2016. HELLNER-ESHED, Melila. A River Flows from Eden: the Language of Mystical Experience in the Zohar. Translated by Nathan Wolski, Stanford University Press, 2009.

LIEBES, Yehuda. Studies in the Zohar. Albany: State University of New York Press, 1993.

SCHOLEM, Gershom. Kabbalah. New York: New American Library, 1978.

House, 1941.

-------- On the Kabbalah and its Symbolism. New York: Schocken Books, 1996.

On the Mystical Shape of the Godhead: Basic Concepts in the Kabbalah. New York:

Schocken Books, 1997.

Tanakh, the Holy Scriptures: The New JPS Translation According to the Traditional Hebrew Text. Philadelphia: The Jewish Publication Society, 1985. 